\title{
Temperature development and damage rates of onion thrips
}

\author{
L.E. Jamieson, A. Chhagan and M. Griffin \\ The New Zealand Institute for Plant E Food Research Limited (Plant E Food Research), \\ Private Bag 92169, Auckland \\ Corresponding author:Lisa.Jamieson@plantandfood.co.nz
}

\begin{abstract}
Bulb damage caused by onion thrips (Thrips tabaci, Thysanoptera: Thripidae) is a serious problem in New Zealand stored export onions. Understanding the relationships between insect development rates, temperature and damage potential is critical to effective pest management by targeting fewer pesticide applications. Thrips development (egg to adult) was monitored daily on leek leaves, onion leaves or onion bulb discs at constant and variable temperatures. Development rates were not significantly different on different substrates, but survival was lower on onion bulbs. Total development time (egg to adult) ranged from 51.1 days at $12^{\circ} \mathrm{C}$ to 10.3 days at $30^{\circ} \mathrm{C}$. Lower development temperature thresholds ranged from $7.3^{\circ} \mathrm{C}$ for pupae to $9.1^{\circ} \mathrm{C}$ for eggs. Accumulation of 221 degreedays above $8.1^{\circ} \mathrm{C}$ was required to complete development. The temperature development model accurately predicted development time of onion thrips under variable temperature conditions. At $21^{\circ} \mathrm{C}$, adults and larvae caused an average of 20.1 and $10.7 \mathrm{~mm}^{2}$ of feeding damage to onion bulbs per day, respectively.
\end{abstract}

Keywords temperature, feeding damage, onion thrips, development rate.

\section{INTRODUCTION}

Damage caused by onion thrips (Thrips tabaci, Thysanoptera: Thripidae) in export consignments has been a serious problem for the New Zealand onion industry since 1997. During the growing season onion thrips feed on onion leaves, causing a silvering damage, and also transmit Iris yellow spot virus (IYSV). Although this feeding damage and virus transmission is reported to reduce yield significantly in onions overseas (Edelson et al. 1989), yields in New Zealand have not been reported to be reduced significantly. The major problem for the New Zealand onion industry is the damage that onion thrips feeding causes to stored onion bulbs (Wood 2001; Jamieson et al. 2002). Onions are stored at ambient temperature before export, and onion thrips feeding damage on bulbs causes blemishes, shrivelling and skin separation, allowing entry and establishment of black mould (Aspergillis niger) (Jamieson et al. 2001). The growth of black mould accelerates when onions are exposed to elevated temperatures during shipping through the tropics to Europe. Presence of thrips in consignments not only lowers the market value of the onions, but also infringes quarantine regulations of importing countries.

Understanding the relationship between insects and temperature is a critical component of pest management. Some life stages of onion thrips are concealed from direct insecticide application (pupae in the soil and eggs under 
the surface of a leaf), while others are generally exposed to insecticides (mobile adults and larvae). Temperature development models can determine the time required to develop from a concealed life stage to an exposed mobile life stage and therefore determine the time required between spray applications in different regions and seasons. The food source of insects can also affect their rate of development, and therefore prediction of the population in the field (on leaves) and in storage (on bulbs) requires an understanding of these interactions with temperature and food source. Overseas research has examined the development of onion thrips under constant temperatures, but none of these studies has been carried out on onion bulbs. Overseas research has estimated variable development thresholds ranging from about $4^{\circ} \mathrm{C}$ (Stacey \& Fellowes 2002) to $11.5^{\circ} \mathrm{C}$ (Edelson \& Magaro 1988). Geographic location and host plant nutritional quality have previously been highlighted as potentially important factors leading to these differences and this emphasises the need for research on development with New Zealand onion thrips strains and hosts.

This research aimed to develop a temperature development model of onion thrips in New Zealand, to validate that model under variable temperatures and to determine the amount of damage that adult and larval thrips cause to onion bulbs.

\section{METHODS}

Onion thrips used in the following trials were collected from a commercial crop in Pukekohe and reared by Crop \& Food Research (now Plant \& Food Research) (Martin \& Workman 2006).

\section{Constant temperature development rates}

Five female adults were place on a leek (sheath) disc $(18 \mathrm{~mm}$ diameter $)$ in a Petri dish $(50 \mathrm{~mm}$ diameter) lined with moist filter paper, and the lid was secured. A total of 2100 female adult onion thrips were placed on 420 leek discs to oviposit at $21^{\circ} \mathrm{C}, 16: 8 \mathrm{~h}$ (light:dark; L:D) for $24 \mathrm{~h}$. Adults were then removed and leek discs with eggs on were placed at $8,12,18,21,25$ or $30^{\circ} \mathrm{C}, 16: 8 \mathrm{~h} \mathrm{~L}: \mathrm{D}$. Only leek sheath discs were used for egg development rates because of problems with maintaining onion leaves in good condition until egg hatch and low rates of egg laying on onion bulb discs. Discs with eggs were checked daily for larval emergence. On the day that a larva emerged, it was transferred to a leek sheath, onion leaf or onion bulb disc. Twenty leek discs and onion leaf discs with a single thrips larva were set up for each temperature. Because of low survival rates on onion bulb discs, 40 were set up for each temperature. Thrips on discs were checked daily and the life-stage recorded. Thrips were placed on fresh discs if the disc was becoming mouldy or drying out.

\section{Validation of temperature development model using variable temperature regimes}

Twenty to 30 discs of leek sheath were set up as above with three female adults to lay eggs. Six replicates were set up and placed into vented plastic containers and maintained at one of six variable temperature locations around the Mount Albert Research Centre campus. Adult thrips were removed after $24 \mathrm{~h}$ and discs checked daily for the presence of thrips larvae. Once larvae emerged, individual thrips were transferred to a fresh leek disc. Twenty leek discs, each with a single thrips larva were set up for each of the six temperature regimes. Thrips were checked daily and the life stage recorded. Leek discs were replaced every 3-5 days when their quality began to decline. Temperature loggers were placed in each of the containers to record the average daily temperature.

\section{Thrips damage}

Dry skins of onion bulbs were removed and adult or larval thrips were caged onto each onion using a feeding arena consisting of a $13 \mathrm{~mm} \times 20 \mathrm{~mm}$ nontoxic clear plastic tubing with metal mesh covering one end and the other attached to the bulbs using Blu-Tack ${ }^{\circledR}$ rings. Either $0,1,3$ or 5 adult or larval thrips were placed within each of four arenas on each onion. This was replicated 12 times. Onions were stored at $21^{\circ} \mathrm{C}$ for $24 \mathrm{~h}$ and the number of thrips remaining was recorded when the arena was removed. The onion bulb area to which the arena had been adhered was then brushed with a mix of blue Vivid ${ }^{\circledR}$ permanent marker pen ink and 75\% 
ethanol. After 0.5-1 h, a grid was used to calculate the area of damage and recorded.

\section{Statistical analyses}

The rate of development (1/time) was compared between temperatures and food sources by ANOVA using Genstat. Least significant differences were calculated post hoc to separate treatments $(\mathrm{P}<0.05)$. The relationship between temperature and developmental rate for each life stage (egg, larval and pupal) was calculated by linear regression analysis.

The developmental threshold temperature $(t)$ is the temperature below which onion thrips cease to develop. The thermal constant $(\mathrm{K})$ is the number of heat units required for onion thrips to develop to the next life stage. The developmental threshold temperature and thermal constant required for each life stage were derived from the regression equation $y=a+b x$, where $y$ is the developmental rate at temperature $\mathrm{x}, \mathrm{a}$ is the $\mathrm{y}$-intercept and $\mathrm{b}$ is the slope. The developmental threshold and thermal constant values were calculated using the following formula $t=(y-a) / b$, where $y$ is set at 0 , to determine the temperature at which development ceases (developmental rate zero). The thermal constant is calculated by $\mathrm{K}=1 / \mathrm{b}$.

For validation of the temperature development model using variable temperatures, the number of degree-days was calculated for each day by subtracting the thermal constant for the appropriate life stage from the mean daily temperature recorded. The predicted number of days to complete each life stage was compared with the actual time observed to complete each life stage. To calculate the maximum number of generations per year, the mean daily temperature for the last 10 years was obtained from MetWatch (http://www.hortplus.metwatch.co.nz) and NIWA (http://www.cliflo.niwa.co.nz) and the accumulated degree-days calculated from 1 July using an overall egg-adult development threshold temperature $\left(8.11^{\circ} \mathrm{C}\right)$. Accumulation of 220.95 days was used to complete a generation and a preoviposition period of 1 day was included in the model, based on research by Martin \& Workman (2006).

\section{RESULTS AND DISCUSSION}

\section{Constant temperature development rates}

Mean onion thrips egg development ranged from 3.4 days at $30^{\circ} \mathrm{C}$ to 17.6 days at $12^{\circ} \mathrm{C}$. None of the eggs placed at $8^{\circ} \mathrm{C}$ hatched. There were no significant differences $(\mathrm{P}>0.05)$ between the development times of larvae and pupae of onion thrips on leeks, leaves and bulbs. However, adults lived for a shorter amount of time on onion bulb discs than on leek or onion leaf discs (Table 1). Survival to the pupal and adult stage was lower on onion bulb discs than on leek and onion leaf discs.

The average developmental times for each life stage of onion thrips at each of the constant temperatures are shown in Table 2. Mean total developmental time (egg to adult) ranged from 51.1 days at $12^{\circ} \mathrm{C}$ to 10.3 days at $30^{\circ} \mathrm{C}$.

Since there was no difference between substrates the data were pooled. There was a significant linear trend of increasing developmental rate with increasing temperature for all life stages (Table 3; $\mathrm{R}^{2}$ values $>0.71$ ). There were significant differences in developmental times between the five constant temperature regimes $(\mathrm{P}$-values $<0.001)$ for all life stages. Estimated lower developmental thresholds for each life stage ranged from 7.3 days for pupae to 9.1 days for eggs, and thermal constants ranged from 63.6 degree-days for pupae to 78.8 degreedays for larvae (Table 3 ).

\section{Validation of temperature development model using variable temperature regimes}

The observed and predicted time to develop through each life stage at each variable temperature regime is shown in Table 4. The duration of each life stage was predicted to within 1 day of the observed duration. Overall, the total time from egg to adult was predicted to within 2 days. Therefore, the model is a good predictor of onion thrips development over a range of variable temperature regimes.

\section{Number of generations each season}

The estimated maximum number of generations of onion thrips for each of the last 13 seasons in Pukekohe, Hawke's Bay and Canterbury is shown in Table 5. In a 'high thrips' year (i.e. 1998/99), 
Table 1 The mean (SEM) adult longevity and percentage of onion thrips that survived to pupa or adult at each constant temperature. N.B. ${ }^{\star}=$ no survival to adult stage.

\begin{tabular}{lcccc}
\hline Food source & $\begin{array}{c}\text { Temperature } \\
\left({ }^{\circ} \mathrm{C}\right)\end{array}$ & $\begin{array}{c}\text { Adult longevity } \\
(\text { days })\end{array}$ & $\begin{array}{c}\text { Survival to pupa } \\
(\%)\end{array}$ & $\begin{array}{c}\text { Survival to adult } \\
(\%)\end{array}$ \\
\hline Leek & 30 & $6.8(2.3)$ & 50 & 25 \\
& 25 & $5.8(1.7)$ & 40 & 25 \\
& 21 & $17.6(2.9)$ & 75 & 60 \\
& 18 & $20.0(0.3)$ & 70 & 70 \\
\hline Onion leaf & $69.6(14.7)$ & 50 & 42 \\
& 30 & $5.3(0.9)$ & 55 & 35 \\
& 25 & $6.8(0.6)$ & 50 & 45 \\
& 21 & $11.4(1.0)$ & 85 & 60 \\
& 18 & $16.7(2.5)$ & 60 & 50 \\
Onion bulb & $34.3(20.7)$ & 27 & 27 \\
& 12 & $*$ & 10 & 0 \\
& 30 & $4.0(2.1)$ & 15 & 10 \\
& 25 & $1.5(0.3)$ & 15 & 7.5 \\
& 21 & $4.7(2.0)$ & 15 & 7.5 \\
\hline
\end{tabular}

Table 2 Mean (SEM) developmental times (days) of onion thrips life stages.

\begin{tabular}{lccccc}
\hline Life stage & $12^{\circ} \mathrm{C}$ & $18^{\circ} \mathrm{C}$ & $21^{\circ} \mathrm{C}$ & $25^{\circ} \mathrm{C}$ & $30^{\circ} \mathrm{C}$ \\
\hline Egg & $17.6(0.2)$ & $8.7(0.1)$ & $6.0(0.2)$ & $4.9(0.1)$ & $3.4(0.1)$ \\
Larva & $19.1(0.6)$ & $8.5(0.2)$ & $6.2(0.2)$ & $4.5(0.2)$ & $3.8(0.1)$ \\
Pupa & $13.8(0.6)$ & $6.6(0.1)$ & $4.7(0.4)$ & $3.7(0.2)$ & $3.0(0.0)$ \\
\hline Egg to adult & $51.1(0.6)$ & $23.3(0.2)$ & $16.8(0.5)$ & $13.0(0.4)$ & $10.3(0.2)$ \\
\hline
\end{tabular}

Table 3 Relationship between temperature and development time of onion thrips and calculated lower development thresholds and thermal constants.

\begin{tabular}{|c|c|c|c|c|c|c|}
\hline Life stage & Regression & $\mathrm{n}$ & $\mathrm{R}^{2}$ & P-value & $\begin{array}{c}\text { Lower } \\
\text { development } \\
\text { threshold }(\mathrm{t}) \\
\left({ }^{\circ} \mathrm{C}\right)\end{array}$ & $\begin{array}{c}\text { Thermal } \\
\text { constant }(\mathrm{K}) \\
\text { (degree-days) }\end{array}$ \\
\hline Eggs & $\begin{array}{l}y=-0.12496+ \\
0.013788 x\end{array}$ & 356 & 0.87 & $<0.001$ & 9.1 & 72.5 \\
\hline Larvae & $\begin{array}{l}y=-0.1047+ \\
0.012693 x\end{array}$ & 134 & 0.81 & $<0.001$ & 8.3 & 78.8 \\
\hline Pupae & $\begin{array}{l}y=-0.1154+ \\
0.01572 x\end{array}$ & 93 & 0.71 & $<0.001$ & 7.3 & 63.6 \\
\hline $\begin{array}{l}\text { Total } \\
\text { (egg to adult) }\end{array}$ & $\begin{array}{l}Y=00.03671+ \\
0.004526\end{array}$ & 93 & 0.93 & $<0.001$ & 8.1 & 221.0 \\
\hline
\end{tabular}


Table 4 Observed development times (days) for each life stage of onion thrips in variable conditions and predicted times using temperature development model.

\begin{tabular}{llrccc}
\hline Variable temp. regime $^{1}$ & & Egg & Larva & Pupa & Egg-Adult \\
\hline A & Predicted & 9.4 & 8.4 & 7.0 & 24.8 \\
$(16.7)$ & Observed & 10.5 & 7.7 & 7.6 & 25.4 \\
\hline B & Predicted & 4.8 & 5.0 & 4.9 & 13.9 \\
$(23.8)$ & Observed & 4.4 & 3.7 & 3.9 & 11.9 \\
\hline $\mathrm{C}$ & Predicted & 8.6 & 8.0 & 6.5 & 23.4 \\
$(17.8)$ & Observed & 8.9 & 7.4 & 7.4 & 24.0 \\
\hline $\mathrm{D}$ & Predicted & 7.1 & 7.0 & 5.0 & 19.3 \\
$(19.7)$ & Observed & 7.4 & 6.2 & 4.9 & 18.6 \\
\hline E & Predicted & 4.6 & 4.7 & 3.9 & 13.6 \\
$(24.3)$ & Observed & 3.8 & 5.3 & 3.4 & 12.4 \\
\hline F & Predicted & 5.2 & 5.5 & 4.5 & 15.6 \\
$(22.2)$ & Observed & 4.0 & 6.1 & 3.6 & 13.7 \\
\hline
\end{tabular}

${ }^{1}$ Mean temperature $\left({ }^{\circ} \mathrm{C}\right)$ given for each temperature regime.

Table 5 Maximum number of onion thrips generations for each season (1 July to 3 June) between 1998 and 2011 in Pukekohe, Hawke's Bay and Canterbury ${ }^{1,2}$.

\begin{tabular}{lccc}
\hline Season & Pukekohe & Hawke's Bay & Canterbury \\
\hline $98 / 99$ & 12.5 & 10.1 & 7.6 \\
$99 / 00$ & 10.8 & 9.1 & 6.8 \\
$00 / 01$ & 10.6 & 8.9 & 6.9 \\
$01 / 02$ & 11.8 & 10.3 & 7.1 \\
$02 / 03$ & 10.9 & 10.0 & 6.9 \\
$03 / 04$ & 10.5 & 8.9 & 6.9 \\
$04 / 05$ & 10.6 & 8.7 & 7.7 \\
$05 / 06$ & 10.9 & 9.0 & 7.6 \\
$06 / 07$ & 10.6 & 8.7 & 7.1 \\
$07 / 08$ & 11.9 & 8.8 & 7.7 \\
$08 / 09$ & 10.4 & 8.9 & 7.2 \\
$09 / 10$ & 10.2 & 8.5 & 6.8 \\
$10 / 11$ & 11.1 & 10.0 & 7.5 \\
\hline
\end{tabular}

${ }^{1}$ Based on the estimated number of degree-days (DD) above $8.1^{\circ} \mathrm{C}$.

${ }^{2}$ Where temperature data were missing (Canterbury 11/09/00, 3/07/04, 8-15/08/05, 16/01/06, 20/02/06, 23/02/06, 27-28/09/06, 19-30/10/06, 18-31/01/07; Hawkes Bay 13/10/99, 11-17/01/01, 29/01/01; Pukekohe 23/07/98, 1/08/98, 3/09/99, 24/07/03, 21/08/03, 24/08/03, 17/10/03, 21/11/03, 25/12/03, $11 / 01 / 04,28 / 05 / 04,12-23 / 01 / 05,8 / 02 / 05)$, the average of temperatures 7 days before and 7 days after was used.

onion thrips were estimated to be able to develop through 12.5, 10 and 8.7 generations in Pukekohe, Hawke's Bay and Canterbury, respectively. In a 'low thrips' year, the number of generations was reduced by ca 2 in each region.

\section{Time between spray intervals}

Table 6 shows the estimated duration of the larval life stage and the subsequent recommended time between sprays for each month in an average year in the three regions. 
Table 6 Estimated time (days) to complete the larval life stage of onion thrips for each month in an average year in Pukekohe, Hawke's Bay and Canterbury.

\begin{tabular}{lcccccc}
\hline & \multicolumn{7}{c}{ Month } \\
\cline { 2 - 7 } Region & October & November & December & January & February & March \\
\hline Pukekohe & 15.3 & 13.3 & 9.3 & 8.3 & 7.8 & 9.1 \\
Hawke's Bay & 16.7 & 15.6 & 9.1 & 8.8 & 9.0 & 10.5 \\
Canterbury & 22.6 & 19.0 & 10.9 & 9.6 & 10.9 & 12.6 \\
\hline
\end{tabular}

\section{Thrips damage}

Adult thrips caused ca $20.1 \mathrm{~mm}^{2}$ of damage/ day and larvae caused ca $10.7 \mathrm{~mm}^{2} /$ day (Table 7). Damage was seen within $24 \mathrm{~h}$ of the thrips feeding.

\section{DISCUSSION}

Knowledge of onion thrips temperature development rates will assist with more appropriate timing of controlling sprays on stored onion bulbs. Martin \& Workman (2006) have shown that adult onion thrips lay fewer eggs on onion bulbs than on onion or leek leaves. Data presented here indicate that although survival from the larval stage to the adult stage is lower on onion bulbs, temperature development rates on onion and leek leaves and onion bulbs do not differ.

It is estimated that onion thrips undergo 10-12 generations per season in Pukekohe, compared with 8-10 in Hawke's Bay and 6-9 in Canterbury, enabling thrips to reach more damaging numbers in Pukekohe. Insecticides targeting onion thrips in New Zealand are currently applied in clusters of 3-4 applications (Martin 2012). The later spray applications in a cluster target those thrips previously hidden from sprays as eggs beneath the surface of the leaf or pupae in the ground. Timing of sprays within these clusters should be based on the number of days for the larval life stage, which can vary between 8 and 23 days depending on the time of year, region and season.

Seasons with high thrips populations recorded in the field and subsequent reduced quality of export onions have generally been the warmer years (e.g. 1998/99 and 2001/02 seasons). The temperature development model can track the number of degree-days accumulated at any stage during the season, and by comparing these with previous seasons, growers can determine if the season is tracking as a 'high', 'medium' or 'low' thrips season. The number of insecticides can then be altered according to the risk predicted (i.e. two well timed sprays per cluster in a 'low' tracking season and three in a 'high' tracking season). Reduction in the number of insecticide

Table 7 The mean damage ( $\mathrm{mm}^{2} /$ day) caused by adult and larval thrips caged on onion bulbs.

\begin{tabular}{lccc}
\hline Life stage & $\begin{array}{c}\text { No. thrips } \\
\text { placed/cage }\end{array}$ & $\begin{array}{c}\text { Mean no. of live thrips } \\
\text { recovered/cage }\end{array}$ & $\begin{array}{c}\text { Mean amount of damage } \\
\text { per thrips }\end{array}$ \\
\hline Adult & 0 & 0 & - \\
& 1 & $0.7 \pm 0.1$ & $16.7 \pm 2.7$ \\
3 & $2.4 \pm 0.4$ & $20.8 \pm 1.8$ \\
\hline Larvae & 0 & $3.5 \pm 0.4$ & $22.8 \pm 1.2$ \\
& 1 & 0 & - \\
& 5 & $0.3 \pm 0.1$ & $14.8 \pm 6.8$ \\
& 5 & $2.0 \pm 0.3$ & $9.2 \pm 2.5$ \\
\hline
\end{tabular}

${ }^{1}$ Damage/thrips based on the average of the number of thrips placed in cage and number of live thrips recovered. 
applications in spray clusters reduces the risk of thrips developing resistance to an active ingredient. Resistance of onion thrips to insecticides has been documented in New Zealand (Martin et al. 2003).

An action threshold is the pest population number at which action (e.g. spray applications) needs to be taken to prevent economic damage. Based on the amount of damage that thrips cause to onion bulbs as described here, it would take 35-66 days for a single adult or larva, feeding linearly, to cause a 15-mm damage band around the entire neck of an average onion bulb. Onions are generally stored for 3-4 weeks or longer before shipping. Therefore, one adult or just a few larvae have the potential to damage an onion bulb substantially during storage, and so the currently recommended low action threshold of five thrips per 50 onions is justified.

During a 6-week storage period, onion thrips could potentially go through two generations on onions while in ambient storage during February, March or April. However, because of the low survival recorded here and low oviposition rates of onion thrips on onion bulbs (Martin et al. 2006), the likelihood of onion thrips populations from field infestations increasing significantly on bulbs in storage is low. However, onion thrips do move around in storage facilities (N.A. Martin, unpublished data), and therefore have the potential to move from onions harvested with high thrips numbers to onions with low thrips numbers. Storing onions at lower temperatures $\left(\mathrm{ca} 8-10^{\circ} \mathrm{C}\right)$ has the potential to reduce onion thrips movement, development and feeding rates in storage.

Inadequate control of onion thrips in the field is probably the result of inadequate timing of spray applications, reduced efficacy of product due to thrips resistance, inefficient spray coverage and/or rapid immigration from surrounding fields (i.e. recently topped/harvested). Research has been carried out to determine the degree to which thrips has developed resistance to classes of insecticides (Martin 2012). The timing of spray applications can now be refined using a temperature development model. Future research on enhancing onion thrips control in the field should focus on improving spray coverage of effective products.

\section{ACKNOWLEDGEMENTS}

We would like to thank Peter Workman and Nick Martin for providing onion thrips.

\section{REFERENCES}

Edelson JV, Magaro JJ 1988. Development of onion thrips, Thrips tabaci Lindeman, as a function of temperature. The Southwestern Entomologist 13(3): 171-176.

Edelson JV, Cartwright B, Royer TA 1989. Economics of controlling onion thrips (Thysanoptera: Thripidae) on onions with insecticides in south Texas. Journal of Economic Entomology 82: 561-564.

Jamieson LE, Chhagan A, Fullerton RA, Tyson JL 2002. Monitoring onion thrips in export onions. Grower 57(10): 20-22.

Jamieson L, Chhagan A, Stevens P, Tyson JL, Fullerton RA 2001. Effect of topping and storage on thrips and black mould in onions. Grower 56(10): 30-31.

Murai T 2000. Effect of temperature on development and reproduction of the onion thrips, Thrips tabaci Lindeman (Thysanoptera: Thripidae), on pollen and honey solution. Applied Entomology and Zoology 35(4): 499- 504.

Martin NA, Workman PJ, Butler RC 2003. Onion thrips (Thrips tabaciLindeman (Thysanoptera: Thripidae)) resistance to insecticides. New Zealand Journal of Crop and Horticultural Science 31 (2): 99-106.

Martin NA, Workman PJ 2006. A new bioassay for determining the susceptibility of onion (Allium cepa) bulbs to onion thrips, Thrips tabaci (Thysanoptera: Thripidae). New Zealand Journal of Crop and Horticultural Science 34: 85-92.

Martin NA 2012. Thrips insecticide resistance management and prevention strategy. http://resistance.nzpps.org/insecticides. php? $\mathrm{p}=$ thrips (accessed 15 April 2012).

Stacey DA, Fellowes MDE 2002. Temperature and the development rate of thrips: Evidence for a constraint on local adaptation? European Journal of Entomology 99: 399-404.

Wood RJ 2001. Control of onion thrips. Grower 56: 51-52. 